\title{
GEOLOGY AND WATER RESOURCES OF THE UPPER McKENZIE VALLEY, OREGON
}

\author{
By Harold T. Stearns
}

\section{INTRODUCTION}

It was the writer's good fortune in the summer of 1926 to be assigned to the investigation of numerous dam and reservoir sites in western Oregon. During this investigation trips were made to many out-of-the-way places. One of these was a trip by pack train up McKenzie River to its source, made in the company of B. E. Jones, chief of the power division, conservation branch, United States Geological Survey, with Arthur Belknap as packer. The writer is indebted to Mr. Jones for arranging the details of the trip and to Mr. Belknap for much information given freely from his intimate knowledge of the valley. Mr. Belknap's father pioneered this region, and it is for him that many of the important features are named. The writer is indebted also to F. F. Henshaw, district engineer, United States Geological Survey, who furnished many records of stream flow.

\section{GEOGRAPHY AND CLIMATE}

McKenzie River, famous for its large trout and beautiful scenery, rises in Linn County, Oreg. Its source is Clear Lake, which lies in the Cascade Range, about 8 miles west of Santiam Pass and about the same distance from Mount Washington, on the summit of the range. McKenzie River flows south about 15 miles, then west about 70 miles to its confluence with Willamette River, near Eugene. (See fig. 19.) The east-west stretch of the valley of the McKenzie is traversed by the State highway from Eugene to Bend and is readily accessible by automobile. The settlement of Belknap Springs lies near the elbow of the river, 2 miles northeast of the highway and 60 miles by road from Eugene. The part of the valley north of Belknap Springs is little known. It has been traversed by forest rangers, hunters, and fishermen, but so far as the writer is aware it has not heretofore been described. This upper valley of the McKenzie, with its hidden falls, unique volcanic features, and remarkable springs, is the subject of this paper. As the five-day reconnaissance in the valley was made for another purpose, these observations are not complete; they are given largely to call attention to this region as a promising field for additional geologic work. 
The climate of the area described is similar to that of much of the western slope of the Cascade Range. The cool summer nights make it an ideal location for summer resorts, and the number of these resorts has increased rapidly since the opening of the State highway

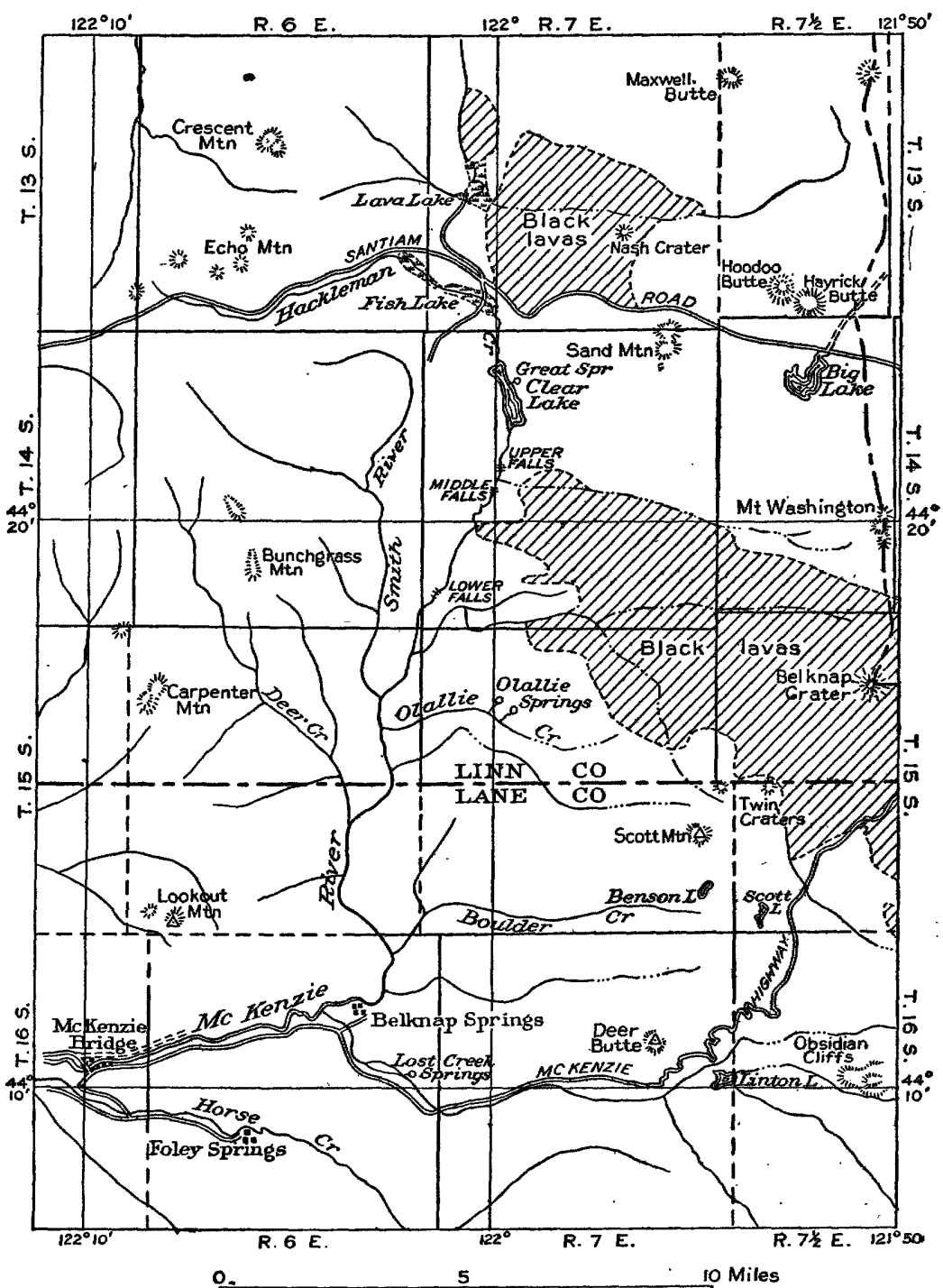

Figure 19.-Map of the upper McKenzie River region, Oregon

over McKenzie Pass. No Weather Bureau station is now maintained in the valley, but during the 12 years 1902 to 1913 , observations were taken at McKenzie Bridge. The highest temperature recorded during that period was $108^{\circ} \mathrm{F}$., and the lowest $0^{\circ} \mathrm{F}$. The mean 
temperatures for 1902 to 1913 are given in the table below. McKenzie Bridge is 1,400 feet above sea level, and the altitude increases rapidly upstream, hence the maximum and minimum temperatures for the area around Clear Lake are considerably lower than those at McKenzie Bridge.

Average temperature $\left({ }^{\circ} \mathrm{F}.\right)$ at McKenzie Bridge, Oreg., 1902-1913

\begin{tabular}{|c|c|c|c|c|c|c|c|}
\hline Month & Mean & $\begin{array}{l}\text { Mean } \\
\text { maxi- } \\
\text { mum }\end{array}$ & $\begin{array}{l}\text { Mean } \\
\text { mini- } \\
\text { mum }\end{array}$ & Month. & Mean & $\begin{array}{l}\text { Mean } \\
\operatorname{maxi}- \\
\operatorname{mum}\end{array}$ & $\begin{array}{l}\text { Mean } \\
\text { mini- } \\
\text { mum }\end{array}$ \\
\hline $\begin{array}{l}\text { January } \\
\text { February } \\
\text { March } \\
\text { April } \\
\text { May }\end{array}$ & \multirow{2}{*}{$\begin{array}{l}34.5 \\
38.7 \\
42.8 \\
48.5 \\
53.4 \\
58.8 \\
65.0\end{array}$} & \multirow{2}{*}{$\begin{array}{l}42.8 \\
49.6 \\
55.9 \\
64.1 \\
68.8 \\
75.4 \\
84.8\end{array}$} & \multirow{2}{*}{$\begin{array}{l}26.3 \\
27.8 \\
29.6 \\
33.0 \\
37.9 \\
42.3 \\
45.3\end{array}$} & \multirow{2}{*}{$\begin{array}{l}\text { August } \\
\text { September } \\
\text { October } \\
\text { November } \\
\text { December } \\
\text { Annual .... }\end{array}$} & $\begin{array}{l}63.2 \\
57.7 \\
51.3 \\
41.9 \\
36.0 \\
\end{array}$ & $\begin{array}{l}84.2 \\
76.0 \\
66.9 \\
52.2 \\
44.9 \\
\end{array}$ & $\begin{array}{l}42.3 \\
39.4 \\
35.6 \\
31.6 \\
28.1 \\
\end{array}$ \\
\hline July & & & & & 49.3 & 62.1 & 34.9 \\
\hline
\end{tabular}

The annual precipitation in the form of rain and snow at McKenzie Bridge amounts to about 70 inches. The precipitation in the upper McKenzie Valley is probably not very different in amount, though during some years it may be as much as 90 inches. The luxuriant forest of magnificent cedars and firs, the long strips of gray moss hanging from the branches of the trees, and the soft green moss which covers the ground beneath constitute mute evidence of the humidity. The available records of precipitation are given in the following tables:

Precipitation, in inches, at McKenzie Bridge, Oreg., 1902-1913

\begin{tabular}{|c|c|c|c|c|c|c|c|c|c|c|c|c|c|}
\hline Year & Jan. & Feb. & Mar. & Apr. & May & June & July & Aug. & Sept. & Oct. & Nov. & Dec. & $\underset{\text { nual }}{\text { An- }}$ \\
\hline & & & & & & & & 15 & & 70 & 11 & 5.30 & \\
\hline & 15.00 & & 5.88 & & & & & & & & & & 64.53 \\
\hline & 12. 04 & 18. 59 & 15.23 & 5.00 & 2.64 & 1.31 & 2.62 & .34 & .53 & $\begin{array}{r}4.43 \\
7\end{array}$ & 5.59 & 13.90 & 82.22 \\
\hline & 5. 24 & 2.27 & 8. 60 & 1.91 & 5. 65 & 2.32 & .52 & .18 & 4. 26 & 7.73 & $\begin{array}{r}\text { 6. } 29 \\
\text { 1. }\end{array}$ & 8.15 & 53.12 \\
\hline & $\begin{array}{r}7.45 \\
12.81\end{array}$ & 8.40 & 3.31 & 2.89 & 4.67 & 5. & .00 & .200 & 4.08 & $\begin{array}{l}6.83 \\
2\end{array}$ & $\begin{array}{ll}14.94 \\
10.74\end{array}$ & 8.99 & $\begin{array}{l}67.33 \\
86.11\end{array}$ \\
\hline & $\begin{array}{r}6.21 \\
6.81\end{array}$ & 5.26 & $\begin{array}{l}6.78 \\
8.82\end{array}$ & $\begin{array}{l}\mathbf{8} . \\
3 .\end{array}$ & 2. & 4. & .00 & $\begin{array}{l}2.79 \\
2.11\end{array}$ & $\begin{array}{c}2.60 \\
.76\end{array}$ & $\begin{array}{r}2.05 \\
10.49\end{array}$ & 5.47 & 7.14 & 58.45 \\
\hline & $\begin{array}{l}0.21 \\
15.75\end{array}$ & $\begin{array}{r}0.20 \\
11.07\end{array}$ & $\begin{array}{l}8 . \\
4 .\end{array}$ & $\begin{array}{l}3.0 \\
1.6\end{array}$ & $\begin{array}{l}0.0 \\
4.0\end{array}$ & $\begin{array}{l}2.08 \\
.71\end{array}$ & $\begin{array}{l}.00 \\
2.64\end{array}$ & .10 & $\begin{array}{l}.60 \\
3.57\end{array}$ & $\begin{array}{r}0.49 \\
5.46\end{array}$ & 21.14 & $\begin{array}{l}7.27 \\
6.27\end{array}$ & $\begin{array}{l}-0.40 \\
77.02\end{array}$ \\
\hline & 7.73 & 11. 31 & 5. & 2.5 & 4.14 & 2.73 & & .08 & 1. 11 & & 18.17 & 7.07 & 65.77 \\
\hline & 5.67 & 4. 51 & 2 & 3 & 5.91 & . & & .05 & 6.34 & & 13. 19 & 7. 19 & 5249 \\
\hline & 17.12 & 11.38 & 4. & 5. & 5. & 4. & & 3. 87 & 2.98 & & 10. 13 & 11.08 & 85.02 \\
\hline & 13.04 & 3.1 & 10. & 3. & 3. & 6. & 1.43 & .97 & 3.02 & 7.46 & 9.95 & & \\
\hline Lean & 10.73 & 8. 65 & 6. 90 & 4.05 & 4. 49 & 2.93 & 1.07 & 1.03 & 2.81 & 5.58 & 12.26 & 10.13 & 70.63 \\
\hline
\end{tabular}

Pręcipitation, in inches, at Clear Lake, Oreg., 1919-1915

\begin{tabular}{|c|c|c|c|c|c|c|c|}
\hline Month & 1913 & 1914 & 1915 & Month & 1913 & 1914 & 1915 \\
\hline $\begin{array}{l}\text { January } \\
\text { Febrraary } \\
\text { March } \\
\text { April } \\
\text { May } \\
\text { June }\end{array}$ & $\begin{array}{r}12.41 \\
2.07 \\
10.42 \\
3.78 \\
4.23 \\
6.25\end{array}$ & $\begin{aligned} 15.84 \\
7.35 \\
4.09 \\
4.46 \\
2.42 \\
2.85\end{aligned}$ & $\begin{array}{l}\text { 7.21 } \\
7.27 \\
3.82 \\
3.08 \\
7.02 \\
1.05\end{array}$ & 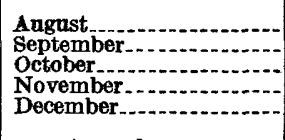 & $\begin{array}{r}0.81 \\
3.77 \\
7.31 \\
10.97 \\
4.67\end{array}$ & $\begin{array}{l}0.00 \\
8.56 \\
6.58 \\
6.15 \\
2.95 \\
\end{array}$ & \\
\hline July & & & & Annual .... & 67.75 & 61.78 & \\
\hline
\end{tabular}




\section{GEOLOGY AND PHYSIOGRAPHY}

\section{GRNRRAL FRATURES}

The only previous geologic work in this area was done by Hodge, ${ }^{1}$ who cites Clear Lake and some of the other features near Santiam Pass as proof of the existence of a buried valley tributary to the valley of Santiam River, which lies north of the McKenzie Valley. The entire area around the upper McKenzie is occupied by basaltic lava flows that issued from numerous vents on the summit of the Cascade Range from the late Tertiary to geologically recent time. Many of the flows are so new as to be nearly bare of vegetation.

Between Belknap Springs and Olallie Creek McKenzie River flows in a relatively wide canyon carved in the older basalt, which may correspond to the Columbia River basalt, but from Olallie Creek upstream (see pl. 21) the canyon narrows and is bordered on the east by a thickly forested bench of intracanyon basalt. At Lower Falls and for several miles upstream this bench is about half a mile wide and terminates in a vertical cliff about 500 feet high facing McKenzie River. From the height and steepness of this cliff, which has been formed entirely by erosion, one would suppose that the river occupies a narrow $V$-shaped gorge in the bottom of the canyon. However, upon descending the dim foot trail to Lower Falls one finds a nearly level valley floor about an eighth of a mile wide. The floor is formed by a flow of olivine basalt that partly fills the gorge. A shallow channel, in places 5 feet deep, has been eroded in this floor. The west wall of the canyon is densely forested and rises less steeply than the east wall but to a greater height. This west wall is much older than the eastern one and is the original wall of the valley of the ancestral McKenzie River.

It is evident that after a wide $V$-shaped canyon had been carved it was filled to a depth of about 650 feet with numerous intracanyon basalt flows. After this epoch of lava filling the river carved a new canyon about 500 feet deep, leaving remnants of the lava fill as a high bench on the east side. Into this later canyon came the flows of olivine basalt that caused Lower, Middle, and Upper Falls, and Clear Lake. The relations of these valleys and flows are shown in Plate 21 and Figure 20.

The lava that forms the valley floor above Lower Falls is of the pahoehoe type, with relatively smooth surface, satiny or shiny crust, and ropy structure. It is full of lava tubes and joints, and the lava domes and other features of the original surface are well preserved. It is of geologically recent origin and may have flowed into the valley within the last thousand years.

1 Hodge, E T., Mount Multnomah, pp. 21, 114, Eugene, Oregon Univ., 1925. 
About 200 feet downstream from Lower Falls and on the west bank of the river there is a vertical tree mold in this flow 12 feet deep and 2 feet in diameter. Others were found in the same area. Tree molds of this type indicate that shells of lava froze around the tree trunks before the wood completely burned away. These molds are all within 25 feet of the margin of the flow, where the lava was sluggish and partly cooled. Tree molds are rarely preserved in the middle of a lava flow because' subsequent movement tilts them over or fills them with lava.

This lava flow entered McKenzie Valley from the east in sec. 29, T. $14 \mathrm{~S}$., R. $7 \mathrm{E}$., or about $11 / 2$ miles above Lower Falls, in the form of a great cascade a quarter of a mile wide, which spread to form a large fan of lava on the valley floor, similar in shape to an alluvial fan.

A

B

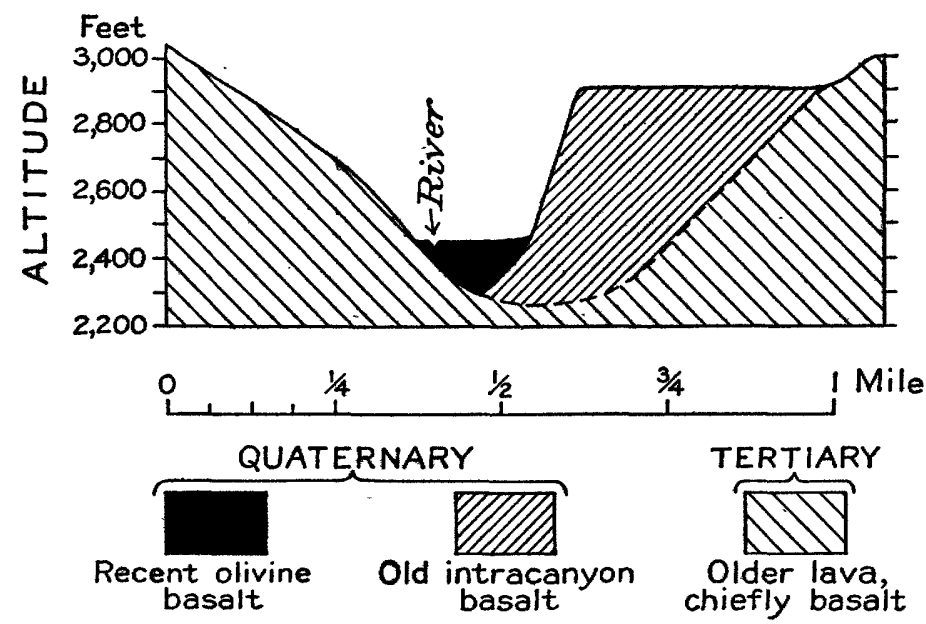

Figure 20.-Geologic section of the McKenzie Valley near Lower Falls, Oreg.

(See pl. 21.) The flow came from the crest of the Cascade Range near Belknap Crater. (See fig. 19.) It is chiefly of the clinkery type of basalt, or aa lava, with the bristling, jagged surface and jumbled blocks produced by the granulation of a stiff, overcooled fluid on the point of solidifying. The lava entering the canyon apparently changed from the pahoehoe to the aa type during the last phases of the eruption. Another large, thick flow of a lava enters McKenzie Valley from the east in secs. 17 and 20, T. 14 S., R. 7 E. (See pl. 21.) This flow caused the Upper and Middle Falls. The lava flows about. Clear Lake are considered in connection with the lake, on pages 176 and 177.

In the face of the nearly vertical cliff in the intracanyon lava on the east side of the valley at Lower Falls are exposed numerous nearly 
horizontal lava beds, and about half a mile above the falls there is a large lava tube or cave in the cliff through which an ancient river of lava flowed.

\section{LOWER FAILS}

The Lower Falls of McKenzie River is in the NE. 1/4 sec. 31, T. 14 S., R. 7 E. It is 60 feet high and is due to the tumbling of the river over the east edge of the last basalt flow where it is in contact with the older intracanyon flows that form the bench on the east side of the valley. At the time of the writer's visit, in September, 1926, Lower Falls was dry. It generally flows only in the spring, for during the rest of the year the water sinks into the permeable lava in the valley floor about $11 / 2$ miles upstream, in the northern part of sec. 30, T. 14 S., R. 7 E., flows underground for this distance of $11 / 2$ miles, and gushes out as a huge spring in the plunge pool at the foot of the falls. In September, 1926, considerable water issued also a few feet above the surface of the pool. (See pl. 22, A.) It is estimated that a total of 350 second-feet of water issued as springs at Lower Falls at the time it was visited.

\section{MIDDLE FALIS}

Middle Falls is in the NE. $1 / 4$ sec. 20 , T. 14 S., R. 7 E. The river at this place makes a magnificent leap from a lava cliff 70 feet high. (See pl. 22, B.) A few springs issue from crevices at the base of the cliff, and the cavernous condition of the basalt back of the falls suggests that perhaps in flood stages of the river there are even larger springs.

\section{UPPER FAILS}

Upper Falls is the grandest cataract on McKenzie River. Here the river makes one great leap of 100 feet over a lava dam and then tumbles in a series of beautiful cascades another 40 feet. (See pl. 23, A.) The falls is in the SE. $1 / 4$ sec. 17 , T. 14 S., R. 7 E., at an altitude of 2,900 feet.

\section{CLEAR IAKS}

Clear Lake lies at the head of McKenzie River in secs. 5 and 8, T. 14 S., R. $7 \mathrm{E}$. It is about a quarter of a mile wide and $11 / 4$ miles long and occupies a narrow valley. (See pl. 21.) It is reported to have a maximum depth of 172 feet. Its waters are extremely clear and of an exquisite green color. During the writer's visit the riotous colors of the autumn foliage were reflected along its shores, and from the northwest side there could be seen framed in the foliage the reflection of the snow-clad slopes and peak of Mount Washington.

The west shore of the lake is a relatively steep soil-covered slope which supports a grow th of giant firs and pines. The east shore rises gently; much of it is covered with rough aa lava of the younger flows, 


\section{EXPLANATION}

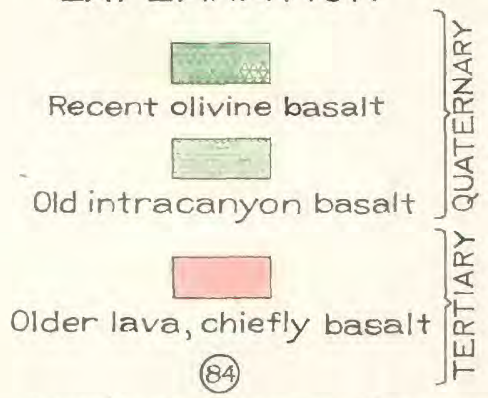

Numbers refer to distance in miles from mouth of McKenzie River 2600

Elevation of river at point indicated
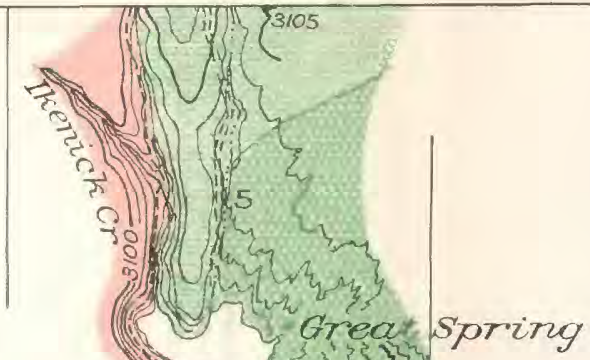

88
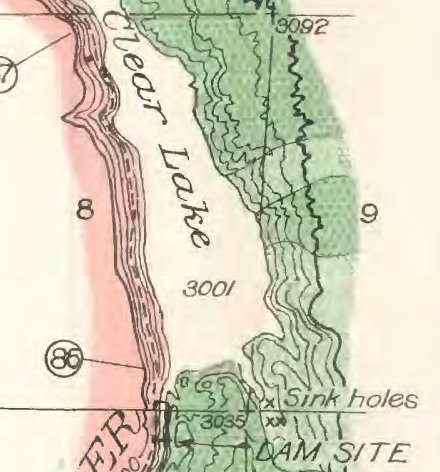
。 



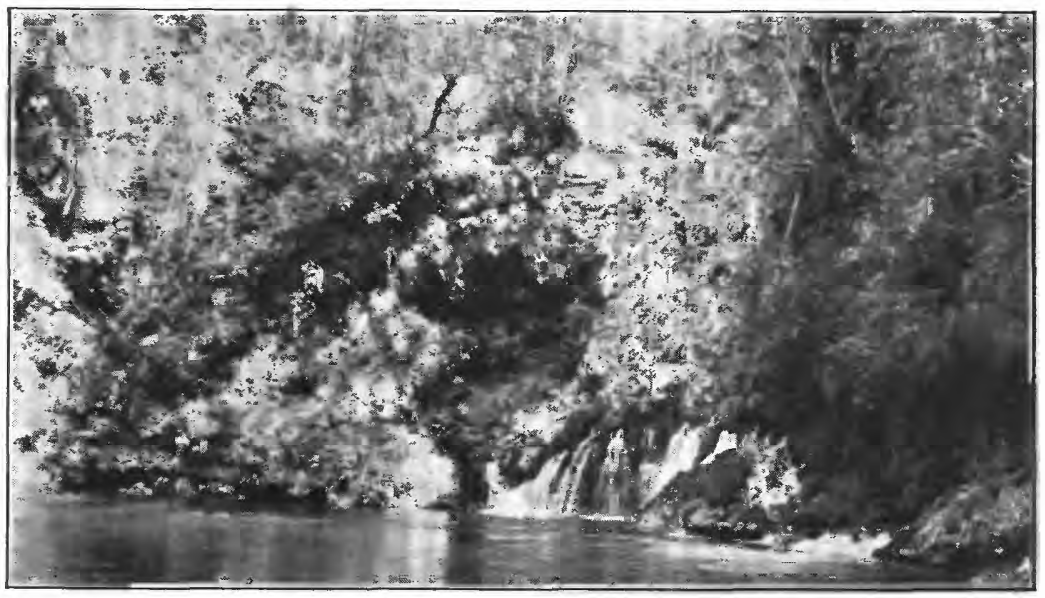

A. SPRINGS AT THE BASE OF LOWER FALLS, McKENZIE RIVER, OREG., SEPTEMBER 4, 1926

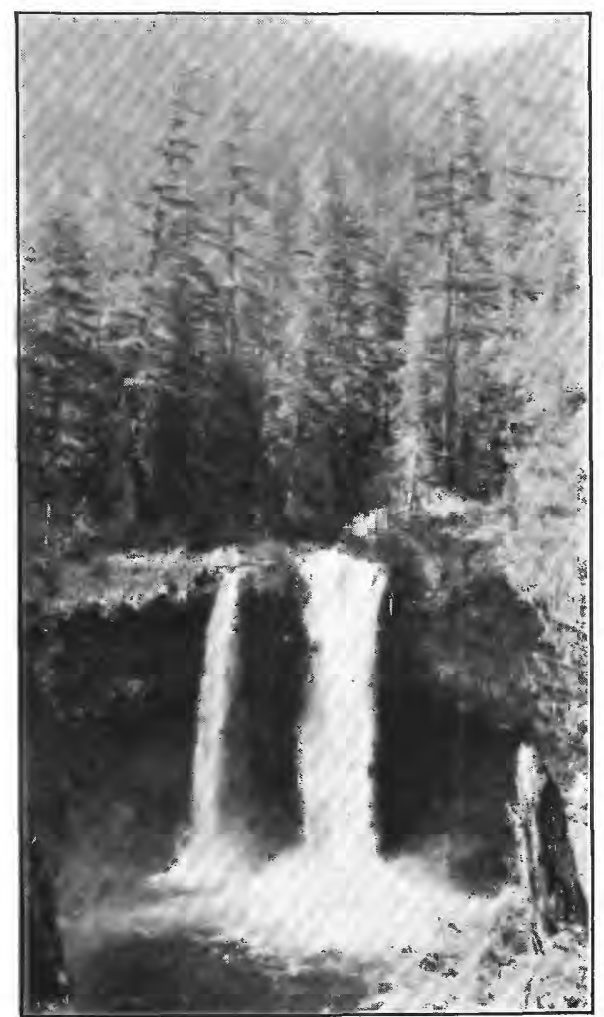

B. MIDDLE FALLS, MCKENZIE RIVER, SEPTEMBER 4, 1926 


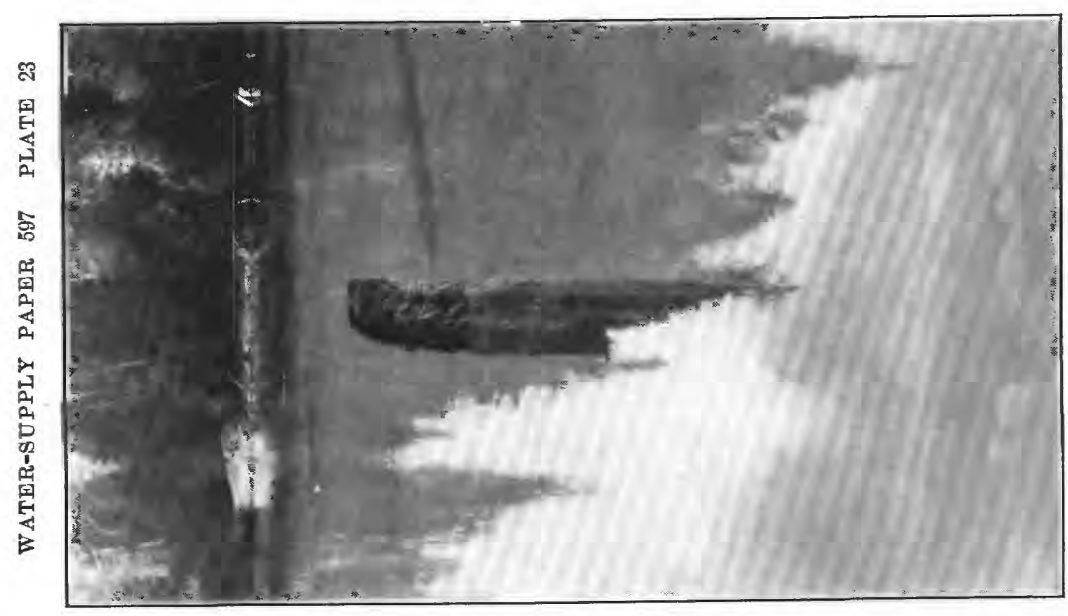

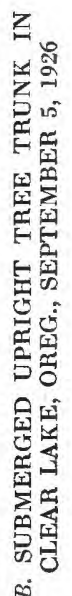

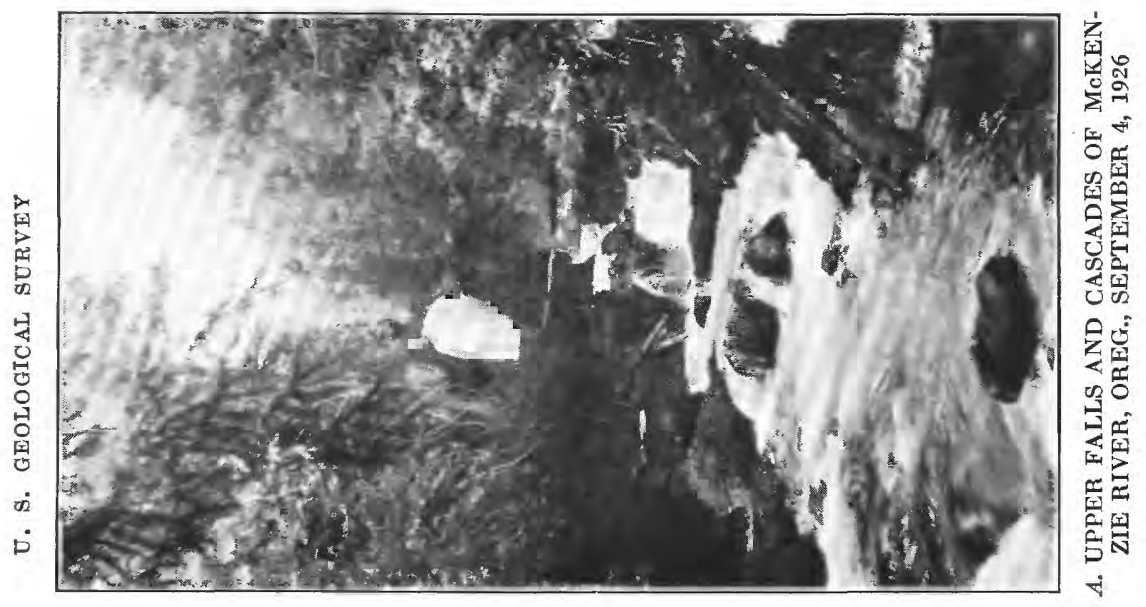


in places bare of vegetation. North of the lake are older basalt flows, which are correlated with the old intracanyon basalt that forms the high bench on the east side of the river at Lower Falls. These bury a valley in still older basalt.

The basin occupied by Clear Lake was formed by a flow of relatively late olivine aa lava that entered the east side of McKenzie Valley near the present outlet of the lake and piled up against the west wall of the valley in the form of a great dam nearly 200 feet high. This lava flow was not traced to its source, but it probably originated at or near Belknap Crater. (See fig. 19.)

At the time the lava entered the valley a forest bordered McKenzie River at this place, for a submerged but still upright forest is visible in the shallow northern part of the lake. The tree trunks, many of them 2 to 3 feet in diameter and 40 feet high, were particularly noticeable during the dry summer of 1926, when the tops of many of them projected a few inches above the water. They have remained erect because the water is not agitated by violent storms or strong currents. Plate 23, $B$, is a view taken from a boat of one of these upright trunks in the clear water. It appears like a tree ghost in the picture, for the lower part (beneath the water) seems to fade away in the reflection of the sky above the living trees that stand on the far shore of the lake.

It is evident that the water of the lake has never stood appreciably lower than it does now, because all the trees rotted off at about the present lake level. They are thoroughly water-logged and are found to be tough when cut with a knife. Around the base of the trees is a laminated deposit of white ooze that may consist of diatoms. The same material covers the entire bottom of the lake and probably gives the water its green color. The trunks are in an excellent state of preservation, and there is no reason to doubt that they will stand much longer, as they are protected by the deposit of ooze, which increases in thickness each year.

The presence of the submerged forest and the fact that the lava dam at the outlet of the lake has been only slightly eroded by MeKenzie River are conclusive evidence that the lake was formed in recent geologic time. At first thought these upright submerged trees seem to indicate a very recent date for the eruption that dammed the lake, but the vegetation on this flow indicates that the trees in the water must have been submerged at least 300 years. The lava dam supports a thick forest, and pine trees 3 feet in circumference lie wasting away on the surface. The dead trees must have been rotting at least 100 years and were probably over 200 years old when they died. An allowance must be made also for the time that elapsed between the eruption of the lava and the beginning of the tree growth. If measurements could be made of the rate of deposition of the ooze 
and of its thickness at the base of the trees, they would be of service in determining the date of the submergence. But evidence does not seem to be available to establish the age of the lava flow at the outlet further than that it is post-Pleistocene and is more than 300 years old. It is apparent, however, that the nearly barren flows on the east shore of the lake and on the adjacent slopes of the Cascade Range were extruded many years later than the lava at the outlet.

The hydrologic relations of Clear Lake are described on page 184.

\section{WATER RESOURCES}

\section{MCKINZIF RIVRR}

The drainage area tributary to McKenzie River above McKenzie Bridge is about 343 square miles, including the basin of Lava Lake, north of Clear Lake, which probably drains into Clear Lake and McKenzie River through underground channels. Without the Lava Lake drainage the area is only about 289 square miles. These areas are estimated from the United States Forest Service map of the Santiam National Forest. All the upper part of the drainage basin is covered with permeable basalt, which obliterates many old divides and has no visible surface run-off even during the wettest months; hence it is difficult to determine the boundaries of the drainage basin.

A gaging station has been maintained on upper McKenzie River at MeKenzie Bridge since August 8, 1910, and one was maintained at the outlet of Clear Lake from June 20, 1912, to July 31, 1915. The following stream-flow records for these stations have been furnished by F. F. Henshaw, district engineer, United States Geological Survey, Portland, Oreg. Daily records for these stations have been published by the United States Geological Survey in the reports on surface water supply for the years prior to 1924 .

\section{M'KENZIE RIVER AT CLEAR LAKE, OREG.}

Location.-In sec. 8, T. 14 S., R. 7 E., at the outlet of Clear Lake in Linn County, about 20 miles northeast of McKenzie Bridge, the nearest post office.

Drainage area. - 90 square miles.

Reconds available.-June 20, 1912, to July 31, 1915.

GAGE.-A float gage in the lake and a vertical staff at the outlet, the latter for checking only.

Discharge measurements.-Made from a suspension footbridge at the outlet.

Channel and control.-Closely compacted volcanic sand and gravel bound together with fine silt. Timber bulkheads on each side. Practically permanent.

EXTREMES OF DISChaRge.-1912-1915: Maximum stage recorded, 10.69 feet May 27 and June 3, 1913 (discharge, 1,130 second-feet); minimum stage recorded, 7.53 feet September 23, 1915 (discharge, 165 second-feet). 
IcE.-Stage-discharge relation unaffected by ice.

Diversion.--None.

Regulation.-None.

Cooperation.-Gage-height record furnished by the Oregon Electric Railway Co.

Monthly discharge, in second-feet, of McKenzie River at Clear. Lake, Oreg., for the years ending September 30, 1912-1915

\begin{tabular}{|c|c|c|c|c|c|c|c|}
\hline Month & $\begin{array}{l}\text { Maxi- } \\
\text { mum }\end{array}$ & $\underset{\text { mumi- }}{\text { Mini- }}$ & Mean & Month & $\underset{\text { mumi- }}{\text { Maxi- }}$ & $\begin{array}{l}\text { Mini- } \\
\text { mum }\end{array}$ & Mean \\
\hline $\begin{array}{l}\text { June 20-30 } \\
\text { Jul2 } \\
\text { July } \\
\text { August } \\
\text { September } \\
\end{array}$ & $\begin{array}{l}577 \\
475 \\
371 \\
337 \\
\end{array}$ & $\begin{array}{l}484 \\
371 \\
298 \\
258 \\
\end{array}$ & $\begin{array}{l}532 \\
415 \\
327 \\
308 \\
\end{array}$ & \multirow{6}{*}{$\begin{array}{l}\text { December } \\
\text { January } \\
\text { February } \\
\text { March } \\
\text { April } \\
\text { May } \\
\text { June } \\
\text { July } \\
\text { August } \\
\text { September The year } \\
\text { 1914-15 } \\
\text { October } \\
\text { November } \\
\text { December } \\
\text { January } \\
\text { February } \\
\text { March } \\
\text { Aprid } \\
\text { May } \\
\text { June } \\
\text { July }\end{array}$} & \multirow{2}{*}{$\begin{array}{l}374 \\
475 \\
442 \\
727 \\
902 \\
649 \\
484 \\
377 \\
268 \\
300\end{array}$} & \multirow{2}{*}{$\begin{array}{l}283 \\
281 \\
323 \\
409 \\
487 \\
491 \\
382 \\
270 \\
223 \\
215\end{array}$} & \multirow{2}{*}{$\begin{array}{l}335 \\
410 \\
373 \\
640 \\
677 \\
576 \\
432 \\
322 \\
244 \\
248\end{array}$} \\
\hline $\begin{array}{l}\text { 1912-13 } \\
\text { October } \\
\text { November } \\
\text { December }\end{array}$ & $\begin{array}{l}305 \\
980 \\
395\end{array}$ & $\begin{array}{l}230 \\
303 \\
332\end{array}$ & $\begin{array}{l}255 \\
542 \\
352\end{array}$ & & & & \\
\hline February & $\begin{array}{l}472 \\
323 \\
419\end{array}$ & 272 & 296 & & 902 & 215 & 411 \\
\hline $\begin{array}{l}\text { April } \\
\text { May } \\
\text { June } \\
\text { August, } \\
\text { September }\end{array}$ & $\begin{array}{r}715 \\
1,130 \\
1,130 \\
745 \\
423 \\
347\end{array}$ & $\begin{array}{l}445 \\
553 \\
745 \\
424 \\
337 \\
276\end{array}$ & $\begin{array}{l}643 \\
869 \\
892 \\
544 \\
384 \\
309\end{array}$ & & \multirow{3}{*}{$\begin{array}{l}328 \\
319 \\
292 \\
242 \\
283 \\
460 \\
645 \\
472 \\
\mathbf{4 4 8} \\
\mathbf{2 8 1}\end{array}$} & \multirow{3}{*}{$\begin{array}{l}256 \\
292 \\
209 \\
209 \\
242 \\
266 \\
414 \\
301 \\
288 \\
201\end{array}$} & \multirow{3}{*}{$\begin{array}{l}\mathbf{2 8 8} \\
304 \\
236 \\
231 \\
\mathbf{2 3 8} \\
\mathbf{3 2 0} \\
\mathbf{5 4 1} \\
\mathbf{4 0 3} \\
\mathbf{3 5 3} \\
\mathbf{2 3 4}\end{array}$} \\
\hline The year & 1,130 & 230 & 484 & & & & \\
\hline $\begin{array}{l}\text { 1913-14 } \\
\text { October- } \\
\text { November }\end{array}$ & $\begin{array}{l}366 \\
364\end{array}$ & $\begin{array}{l}269 \\
307\end{array}$ & $\begin{array}{l}328 \\
343\end{array}$ & & & & \\
\hline
\end{tabular}

\section{M'KENZIE RIVER AT M'KENZIE BRIDGE, OgEG.}

Location.-In sec. 14, T. 16 S., R. 5 E., at highway bridge at McKenzie Bridge, Lane County.

Drainage area.-343 square miles of Lava Lake drainage is considered a part of McKenzie River drainage; otherwise 289 square miles.

Records available.-August 8, 1910, to September 30, 1926, with some breaks. GAGE.-Vertical staff attached to right abutment of highway bridge at McKenzie Bridge. Gages at Paradise Ranger station, 2 miles upstream, and at Hayes ranch, half a mile upstream, have been used at times.

Discharge measurements.-Made from cable three-eighths of a mile above the ranger station.

Channel and control.-Rocky and gravelly; fairly permanent, except in extreme floods.

Extremes of Discharge.-1910-1926: Maximum stage recorded, 8.3 feet on January 6, 1923, determined by leveling to high-water marks (discharge from extension of rating curve, 18,000 second-feet); minimum discharge, 890 second-feet, October 13 to 26, 1924.

IcE.-Stage-discharge relation unaffected by ice.

Diversions.- None.

Regulation.-None. 
Monthly discharge, in second-feet, of McKenzie River at McKenzie Bridge, Oreg., for the years ending September 30, 1911-1926

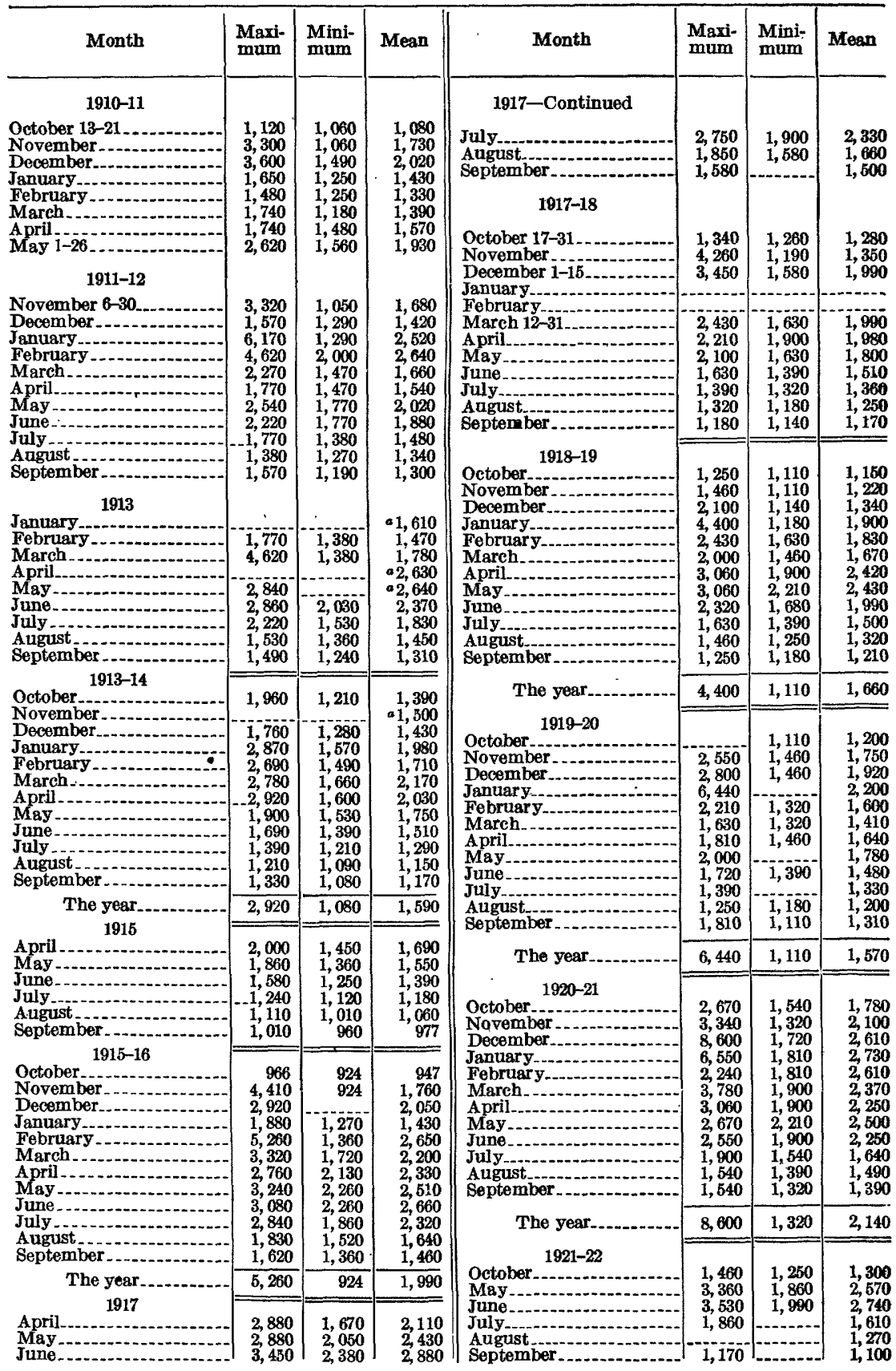

a Estimated by comparison with Clear Lake record. 
Monthly discharge, in second-feet, of McKenzie River at McKenzie Bridge, Oreg., for the years ending September 30, 1911-1926-Continued

\begin{tabular}{|c|c|c|c|c|c|c|c|}
\hline Month & $\begin{array}{l}\text { Maxi- } \\
\text { mum }\end{array}$ & $\begin{array}{l}\text { Mini- } \\
\text { mum }\end{array}$ & Mean & Month & $\begin{array}{l}\text { Maxi- } \\
\text { mum }\end{array}$ & $\begin{array}{l}\text { Mini- } \\
\text { mum }\end{array}$ & Mean \\
\hline 1922 & & & & 1924 & \multirow{10}{*}{$\begin{array}{r}1,860 \\
3,860 \\
2,550 \\
5,370 \\
7,420 \\
1,840 \\
2,550 \\
2,430 \\
1,840 \\
1,430 \\
1,310 \\
1,190\end{array}$} & \multirow{10}{*}{$\begin{array}{r}890 \\
1,350 \\
1,470 \\
1,590 \\
1,840 \\
1,550 \\
1,590 \\
1,840 \\
1,430 \\
1,310 \\
1,160 \\
1,100\end{array}$} & \multirow{10}{*}{$\begin{array}{r}97 \\
\mathbf{2}, 05 \\
1,73 \\
2,44 \\
3,37 \\
1,68 \\
1,89 \\
1,96 \\
1,65 \\
1,39 \\
1,21 \\
1,14\end{array}$} \\
\hline October & 1,080 & 962 & 1,000 & October..... & & & \\
\hline December & & 944 & 965 & December. & & & \\
\hline April 7-30. & 2,410 & 2,130 & 2,310 & January. & & & \\
\hline May & 4,240 & 2,130 & 2,560 & February -.. & & & \\
\hline June. & 2,410 & 1,800 & 2,060 & March...... & & & \\
\hline July. & 1,800 & 1,500 & 1,590 & April $\ldots$ & & & \\
\hline August & $\begin{array}{l}1,500 \\
1,320\end{array}$ & $\begin{array}{l}1,350 \\
1,170\end{array}$ & $\begin{array}{l}1,450 \\
1,230\end{array}$ & June............. & & & \\
\hline $1923-24$ & & & \multirow{12}{*}{$\begin{array}{r}1,250 \\
1,280 \\
2,190 \\
2,070 \\
2,750 \\
1,660 \\
1,570 \\
1,440 \\
1,210 \\
1,100 \\
1,000 \\
963\end{array}$} & Angust & & & \\
\hline October & & 1,170 & & Septemb & & & \\
\hline & \multirow{10}{*}{$\begin{array}{l}2,410 \\
3,880 \\
3,880 \\
4,600 \\
1,990 \\
1,610 \\
1,610 \\
1,280 \\
1,170 \\
1,050 \\
1,020\end{array}$} & 1,120 & & & & & \\
\hline Dece & & & & The year. & 7,420 & 890 & 1,780 \\
\hline $\begin{array}{l}\text { Janu } \\
\text { Febr }\end{array}$ & & $\begin{array}{l}1,610 \\
1,990\end{array}$ & & $1926-26$ & \multirow{9}{*}{$\begin{array}{l}1,100 \\
1,200 \\
1,430 \\
1,270 \\
1,200 \\
1,070 \\
1,050 \\
1,060\end{array}$} & \multirow{9}{*}{$\begin{array}{r}1,050 \\
1,030 \\
1,170 \\
1,200 \\
1,070 \\
983 \\
962 \\
934\end{array}$} & \multirow{9}{*}{$\begin{array}{r}1,070 \\
1,100 \\
1,260 \\
1,240 \\
1,120 \\
1,020 \\
979 \\
\mathbf{9 6 9}\end{array}$} \\
\hline Mar & & 1,390 & & October & & & \\
\hline April. - & & 1,500 & & November - & & & \\
\hline May & & 1,270 & & December $1-16$. & & & \\
\hline June & & 1,150 & & May $19-31$ & & & \\
\hline July & & 1,050 & & June.... & & & \\
\hline Augh & & 980 & & July _- & & & \\
\hline & & 908 & & \multirow{2}{*}{$\begin{array}{l}\text { August. } \\
\text { September. }\end{array}$} & & & \\
\hline $\mathbf{T h}$ & 4,600 & 908 & 1,540 & & & & \\
\hline
\end{tabular}

Miscellaneous discharge measurements of upper McKenzie River

\begin{tabular}{|c|c|c|}
\hline Date & Locality & $\begin{array}{l}\text { Discharge } \\
\text { (second- } \\
\text { feet) }\end{array}$ \\
\hline Sept. 12, 1913 & $\begin{array}{l}\text { 11/2 miles below Clear Lake and about } 1 / 2 \text { mile below Middle Falls, in sec. } 20 \text {, } \\
\text { T. } 14 \text { S., R. } 7 \text { E }\end{array}$ & 642 \\
\hline Aug. 8,1924 & $\begin{array}{l}\text { Trail bridge } 3 / 2 \text { mile below outlet of clear Lake, in the NE. } 1 / 4 \text { sec. 17, T. } 14 \text { S, } \\
\text { R. } 7 \text { E }\end{array}$ & 172 \\
\hline
\end{tabular}

\section{SPRITGS}

\section{BELKNAP HOT SPRINGS}

The Belknap Hot Springs issue from several vents in coarse consolidated conglomerate of unknown age on the north bank of McKenzie River near the point where the river turns westward, in sec. 11, T. 16 S., R. 6 E. A small cold spring issues a short distance upstream from the hot springs. At the main vent the temperature of the water on September 4, 1925 , was $180^{\circ} \mathrm{F}$., and the discharge was about 50 gallons a minute. At two other vents on the same day the temperature was $174^{\circ}$ and $147^{\circ} \mathrm{F}$. The total discharge of all the hot springs is about 75 gallons a minute of mineralized water. A part of the hot water is conducted in pipes through the water of the river and cooled sufficiently in this way for use in the natatorium. The remainder is carried across the river in a wooden flume and used for baths. A hotel and several cottages for campers are located on the south bank of the river. 


\section{LOST CREEK SPRINGS}

Lost Creek Springs issue in sec. 19, T. 16 S., R. 7 E., in a pool of clear water at the terminal margin of a flow of rough a basalt. Lost Creek originates in these springs and after flowing 2 miles northwest joins McKenzie River about a mile below Belknap Hot Springs. White Branch, its only tributary, joins it about three-quarters of a mile below the springs. White Branch is fed by Collier Glacier, on the summit of the Cascade Range, and carries considerable water during the period when the ice is thawing, but at other times its flow is small. A measurement of this creek at the foot of the glacier on September 10, 1912, gave a discharge of only 2.2 second-feet, and on September 7, 1926, it was less than 1 second-foot. The large spring pool at the head of Lost Creek had a temperature of $42^{\circ} \mathrm{F}$. on September 7, 1926. Discharge measurements of Lost Creek are given below.

Miscellaneous discharge measurements of Lost Creek, Oreg.

\begin{tabular}{|c|c|c|c|}
\hline Date & Locality & $\begin{array}{c}\text { Gage } \\
\text { height } \\
\text { (feet) }\end{array}$ & $\mid \begin{array}{c}\text { Discharge } \\
\text { (second- } \\
\text { feet) }\end{array}$ \\
\hline Oct. 10,1910 & Highway bridge, near mouth, in NE. $1 / 4$ sec. 15 , T. $16 \mathrm{~S}$., R. $6 \mathrm{E}$ & & 201 \\
\hline Mar. 11, 1911 & [-do- & 0.79 & 1919 \\
\hline $\begin{array}{l}\text { Jnly } 20,1911 \\
\text { Nov. 18,1911 }\end{array}$ & -...do- & 1.60 & 259 \\
\hline Sept. 11, 1912 & White Branch of Lost Creek near mouth.... & & 57 \\
\hline Sept. 26, 1915 & Highway bridge, near month, in NE. 1/4 Bec. 15, T. 16 S., R. 6 E. & .80 & 184 \\
\hline
\end{tabular}

During the summer of 1926 , B. E. Jones, of the United States Geological Survey, maintained a station on Lost Creek in connection with power studies. The flow during this period is given in the following table:

Discharge, in second-feet, of Lost Creek at highway bridge, near mouth, in NE. 1/4 sec. 15, T. 16 S., R. 6 E., in 1926

\begin{tabular}{|c|c|c|c|}
\hline Month & Maximum & Minimum & Mean \\
\hline $\begin{array}{l}\text { June } 26-31 \\
\text { July } \\
\text { August } \\
\text { September- } \\
\text { Oetrober } \\
\text { November } 1-277_{-}\end{array}$ & $\begin{array}{l}235 \\
238 \\
214 \\
199 \\
193 \\
257\end{array}$ & $\begin{array}{l}227 \\
204 \\
186 \\
163 \\
163 \\
170\end{array}$ & $\begin{array}{l}231 \\
2260 \\
200 \\
180 \\
171 \\
200\end{array}$ \\
\hline
\end{tabular}

It is safe to assume that the minimum flow during September, October, and November consisted only of water diseharged by the large springs at the head of Lost Creek, for during the low-water periods in these months there is practically no surface water entering the creek. Thus the group of springs at the head of the creek discharged at least 160 second-feet during the summer of 1926, a year when the discharge of streams of the region was the lowest on record. 
The aa lava from which the springs issue fills the former valley of Lost Creek. It is reported that Lost Lake, also known as Linton Lake, in sec. 13 , T. $16 \mathrm{~S}$., R. $7 \mathrm{E}$., about 6 miles to the east, is the source of the water of the springs. This lake was not visited, but it is believed that a good part of the spring water is derived from permeable basalt to the northeast of the lake. These basalt flows occupy and in places obliterate a long, broad subdrained glaciated valley.

\section{OLALLIE SPRINGS}

Olallie Creek rises in springs in old basalt in sec. 8, T. 15 S., R. 7 E., and flows southwestward for a distance of $11 / 2$ miles to McKenzie River. The creek heads in two short tributaries, each of which occupies a narrow ravine in the lava. The north fork is only twofifths of a mile long and has its source in two large springs that issue about 20 feet above the bed of the creek. The temperature of the water of the upper and larger spring on September 3, 1926, was $40^{\circ}$ F. These springs come from cavernous aa clinker at the contact of two basaltic lava flows that appear to occupy and partly fill a former wide canyon. Minor springs issue at the edge of the creek near by and contribute to its flow. The south fork of Olallie Creek has its source less than a quarter of a mile from the confluence with the other fork, in a large spring in the bed of the channel.

Discharge measurements of Olallie Creek, Oreg.

\begin{tabular}{|c|c|c|}
\hline Date & Locality & $\begin{array}{c}\text { Discharge } \\
\text { (second- } \\
\text { ffet) }\end{array}$ \\
\hline $\begin{array}{l}\text { May 13,1924 } \\
\text { Aug. 12,1924 }\end{array}$ & 600 feet above the mouth, in the SW. $1 / 4$ sec. 12 , T. $15 \mathrm{~S} .$, R. 6 E. & ${ }_{197}^{165}$ \\
\hline $\begin{array}{l}\text { July } 20,1926 \\
\text { Sept. } 6,1926\end{array}$ & Just below the confluence of the two forks & $\begin{array}{l}135 \\
139\end{array}$ \\
\hline
\end{tabular}

The flow of 139 second-feet on September 6, 1926, was derived entirely from springs rising within an area of 1 square mile in the headwaters of this creek. It appears, therefore, from the few measurements available that the discharge of these springs is considerably over 100 second-feet throughout the summer.

\section{GREAT SPRING}

Great Spring issues quietly in a pool of green water from a nook in the margin of a fresh flow of a basalt about 200 feet from the northeast shore of Clear Lake, in the SW. 1/4 SE. 1/4 sec. 5, T. 14 S., R. 7 E. On September 5,1926 , it had a temperature of $39^{\circ} \mathrm{F}$. and a discharge of about 30 second-feet. The water flows westward into Clear Lake. 
The exact source of the spring is unknown, but the fresh lava flow from which it issues apparently buries a creek that was formerly tributary to McKenzie River. The water is evidently derived from precipitation that has percolated through the extremely permeable basalts to the east and has gathered as an underground stream in this lava-filled valley.

\section{CLear IAkE}

SOURCE OF THE WATER

The physiographic relations of Clear Lake have been described on page 176. During the late summer and fall this lake has no surface tributaries except Great Spring and Ikenick Creek, a small creek tributary to the northwest end of the lake. The total flow of these two creeks does not exceed 35 second-feet during the fall, yet the discharge from Clear Lake is considerably more. Measurements made at the gaging station on McKenzie River at the outlet of this lake are given on page 179. The minimum discharge recorded at this station was 165 second-feet on September 28, 1915. If not more than 35 second-feet was entering the lake from Great Spring and Ikenick Creek, 130 second-feet must have been discharged from springs in the bottom of the lake. As the discharge at that time was abnormally low, it is probable that 200 second-feet or more is the usual increment from springs in the bottom of the lake. The lake is therefore a great spring pool where an underground river finds its way to the surface. It is probable that the drainage from Lava Lake, to the north, forms part of this subterranean flow into Clear Lake and McKenzie River. The temperature of the lake was measured in several places on September 6, 1926, and found to range from $50^{\circ}$ to $52^{\circ} \mathrm{F}$. The wide difference between the temperature of the lake water and that of Great Spring is probably due largely to the warming of the lake water by the sun.

Clear Lake occupies a part of the ancestral valley of McKenzie River. This valley can not be traced in the area north of the lake, as that area is covered by lava flows. Observations indicate that the ancient McKenzie River carved out a wide and deep canyon with many tributaries on the slope of the Cascade Range, but the numerous lava flows have completely buried all traces of the former stream pattern. The lava is chiefly permeable basalt, and it is through the cavities and interstices in this lava that the ground water flows. Hence many of the former streams continued to flow in practically the same channels but beneath the surface. As the part of the valley now occupied by Clear Lake was not filled with lava, it became the exit for the subterranean McKenzie River, and the lava dam at the outlet caused the formation of a lake instead of the usually relatively small spring pool. 


\section{LEAKS}

During the examination of Clear Lake as a possible reservoir site the writer was attracted to its southeast corner by the great quantities of driftwood lodged there. . As the wind rarely blows from the northwest at this lake it was surmised that the driftwood was carried by a lake current.

Close inspection revealed a muddy channel 30 feet wide, filled with driftwood, which leads southeastward. During slightly higher stages of the lake the channel is evidently submerged. In its first 200 feet the channel contained numerous small springs which had a temperature of $40^{\circ} \mathrm{F}$. on September 5, 1926, and a discharge of about 8 second-feet. About 300 feet from the lake the channel ended abruptly against the margin of the aa lava flow that dammed the valley, and the entire flow of the springs cascaded into a sink hole partly filled with driftwood. The hole is about 10 feet in diameter and 3 feet deep, with a distinct funnel shape. Numerous holes of similar shape filled with water were found near by. These holes apparently constitute leaks only during high stages of the lake. Because of these leaks it was considered not feasible to make a storage reservoir of the lake. Further evidence of leakage through the lava dam is afforded by the net gain in the flow of McKenzie River $11 / 2$ miles below the outlet. (See p. 187.)

\section{QUANTITY OF GROUND WATHR}

The flow of McKenzie River at McKenzie Bridge during the lowwater periods is derived chiefly from spring flow above the gaging station. Besides Olallie and Lost Creeks, which are spring fed, nine small surface streams enter McKenzie River above McKenzie Bridge during the low-water periods; these are Smith River and Anderson, Deer, Frissell, Boulder, Scott, Kink, Bobby, Payne, and Carmen Creeks. The last four are short and unimportant. Deer Creek, on August 30, 1912, had a discharge at its mouth, in sec. 26, T. 15 S., R. 6 E., of 19.9 second-feet. The discharge of Smith River at its mouth, in sec. 11, T. 15 S., R. 6 E., on August 26, 1912, was 20.6 second-feet, and on June 26, 1913, 154 second-feet. During August and September this river rarely flows more than 25 secondfeet. The discharge of Anderson Creek is about 20 second-feet during periods of low water; it is reported to have its source in a spring. The total flow of all the other tributaries during low-water periods probably does not exceed 50 second-feet, and part of this amount is reported to come from springs not far from the river. The source of the water in Deer Creek and Smith River during low-water periods is unknown, but the water is probably not chiefly derived from springs. Hence, in any calculation of the amount of ground water entering McKenzie River, at least 40 second-feet should be deducted for the 
flow of Smith River and Deer Creek, and a total of about 100 secondfeet for all tributaries discharging other than spring water. The minimum flow on record of McKenzie River at McKenzie Bridge was 890 second-feet, in October, 1924. On the assumption that 100 second-feet was contributed to the river during this month by the surface tributaries, 790 second-feet was discharged by springs above the gaging station.

The available records of minimum discharge of McKenzie River at McKenzie Bridge for the low-water months of August, September, and October are given in the following table:

Minimum discharge, in second-feet, of McKenzie River at McKenzie Bridge, Oreg., for August, September, and October, 1910 to 1926

\begin{tabular}{|c|c|c|c|c|c|c|c|}
\hline Year & August & September & October & Year & August & September & October \\
\hline $\begin{array}{l}1910 \\
1912 \\
1913 \\
1914 \\
1915 \\
1916 \\
1917 \\
1918\end{array}$ & $\begin{array}{l}1,270 \\
1,360 \\
1,090 \\
1,010 \\
1,520 \\
1,580 \\
1,180\end{array}$ & $\begin{array}{r}1,190 \\
1,240 \\
1,080 \\
960 \\
1,360 \\
1,140\end{array}$ & $\begin{array}{r}1,060 \\
1,210 \\
924 \\
1,260 \\
1,110\end{array}$ & \begin{tabular}{|l}
1919 \\
1920 \\
1921 \\
1922 \\
1923 \\
1924 \\
1925 \\
1926
\end{tabular} & $\begin{array}{r}1,250 \\
1,180 \\
1,390 \\
1,350 \\
980 \\
1,160 \\
962\end{array}$ & \begin{tabular}{r}
1,180 \\
1,110 \\
1,320 \\
\hdashline 1,170 \\
908 \\
1,110 \\
934
\end{tabular} & $\begin{array}{r}1,110 \\
1,540 \\
1,250 \\
602 \\
1,170 \\
890 \\
1,050\end{array}$ \\
\hline
\end{tabular}

Oct. 13-21.

The average minimum flow during the 14 years for which low-water records are available is 1,077 second-feet. The average direct run-off at the lowest stages of the river is almost certainly not over 150 second-feet. Hence, the average discharge from springs above McKenzie Bridge at the lowest stages is at least 925 second-feet. How much more is contributed by springs during periods of high water can not be ascertained from existing data. The writer estimates from miscellaneous measurements that at least 520 second-feet of the flow from springs at low stages is contributed from the four largest spring groups, in approximately the amounts given in the table below. These amounts are slightly greater than was observed in 1926 because that was an unusually dry year.

Average low-water flow of large springs tributary to upper McKenzie River, Oreg.

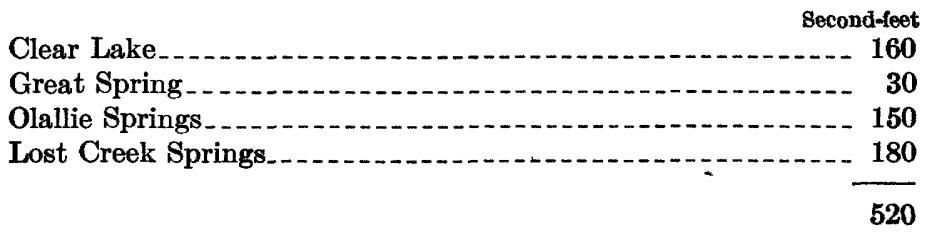

The flow on September 12, 1913, at the outlet of Clear Lake, according to the daily-discharge records, ${ }^{2}$ was 319 second-feet. A measurement of McKenzie River made on the same day $1 \frac{1}{2}$ miles

U, S., Gệl. Survey Water-Supply Paper 362, p. 147, 1917. 
below Clear Lake and about half a mile below Middle Falls, in sec. 20, T. 14 S., R. 7 E., showed a flow of 642 second-feet. No surface streams enter the river between these two points, hence the net gain in $11 / 2$ miles of the McKenzie channel on this date was 323 second-feet. Only a very small part of this inflow can be seen as springs entering from the bank of the river. The remainder must therefore issue as springs in the bed of the river. Most of this inflow is believed to be leakage from Clear Lake that finds its way through the natural lava dam at its outlet. Considerable water issues as small springs at the base of Lower Falls. An analysis of the low-water discharge of McKenzie River above McKenzie Bridge is given below. These quantities are only approximate because of the lack of sufficient data for a more refined analysis, but they show in a general way the source of the low-water flow.

Sources of the low-water flow of McKenzie River above McKenzie Bridge, Oreg.

Second-feet

Approximate direct run-off _... . . . .

Discharge of Clear Lake and of Great, Olallie, and Lost Creek

Springs_........... 520

Spring inflow in $11 / 2$ miles of channel below Clear Lake ..... 325

Other spring inflow................... 82

1,077

Complete records of precipitation and run-off are available for comparison for the hydrographic years ending September 30, 1912, and September 30, 1914. During the year ending September 30, 1912, a total precipitation of 79.91 inches was recorded at McKenzie Bridge. The run-off for 1912 at McKenzie Bridge was 1,160,000 acre-feet, which is equivalent to a run-off of 63.40 inches for the drainage basin of 343 square miles above the gaging station. During the year ending September 30, 1914, a total precipitation of 69.05 inches was recorded at Clear Lake, in the upper part of the drainage basin. The run-off for 1914 at McKenzie Bridge was 1,150,000 acrefeet, which is equivalent to a run-off of 62.86 inches. Thus the records for these two years indicate that a large proportion of the annual precipitation in the drainage basin appears as run-off.

It is estimated that at least 670,000 acre-feet was discharged from springs within the basin during each of these years. This flow from springs is equivalent to an intake of 36.62 inches over the entire drainage area, or nearly 60 per cent of the annual run-off and about 50 per cent of the annual precipitation. As springs of McKenzie Valley are practically all fed from the lava beds on the east side of the McKenzie drainage basin it is very probable that at least 75 per cent of the precipitation on these recent lava beds finds its way to the water table.

$100370^{\circ}-29-13$ 


\section{SUMMARY}

Two epochs of lava filling with the resulting formation of lakes, waterfalls, subterranean streams, and large springs are the outstanding features in the geologic development of the upper McKenzie River Valley. The presence of an upright submerged forest in the bottom of Clear Lake, which was ponded by a lava flow; is proof that the volcanic action at that point was relatively recent. Other lava flows in the valley may be still younger.

The run-off for the drainage basin for the year ending September 30,1912 , was 63.40 inches, and that for the year ending September 30,1914 , was 62.86 inches. From an analysis of the stream-flow records it appears that the flow from springs is equivalent to an intake of 36.63 inches over the entire drainage area, or nearly 60 per cent of the annual run-off, about 50 per cent of the total annual precipitation, and about 75 per cent of the annual precipitation over the intake area of permeable basalt that supplies the springs. It is estimated that the flow from springs in the upper McKenzie Valley is about 925 second-feet, or about 670,000 acre-feet a year. Of this amount about 520 second-feet rises in four spring groups. All these springs issue from basalt, and three of them discharge about 150 second-feet each. The size of the springs is evidence of the remarkable permeability of the basaltic flows of this region.

Visible leaks on the southeast shore of Clear Lake indicate that this lake is unfit for use as a storage reservoir. 